\title{
Pharmacognostic evaluation, physicochemical standardization and HPTLC fingerprint analysis of pomegranate (Punica granatum L.) leaf and seed
}

\author{
Baira Venkatesham, Dandu Chaithra, Mohammed Abdul Rasheed Naikodi ${ }^{\star}$, Mohd Nazeer, Aslam Siddiqui, Javed Inam \\ Siddiqui and Ahmed Minhajuddin \\ Drug standardization Research Unit, National Research Institute of Unani Medicine for Skin Disorders, A.G. Colony Road, Erragadda, \\ Hyderabad-500038, Telangana State, India
}

\section{Article Info}

Article history

Received 1 July 2021

Revised 19 August 2021

Accepted 20 August 2021

Published Online 30 December 2021

\section{Keywords}

Punica granatum L.

Pharmacognosy

Physicochemical

HPTLC

Unani single drug

\begin{abstract}
Punica granatum L. is most important economical crops around the globe. Pomegranate, an ancient fruit associated with several health benefits and human cultures. Its seed juice possess rich source of polyphenols, caffeic acid, quercitin, ascorbic acid and rutin with strong antioxidant, antihypertensive, antiatherogenic and anti-inflammatory properties. It also reduces risks of cancer, inflammation and cardiovascular diseases. An attempt has made to assess the scientific appraisal of $P$. granatum of leaf and seed of pharmacognostical characters and physicochemical parameters, HPTLC fingerprint pattern. Pharmacognostic study describes the characteristic features of the leaf and seed including powder microscopy. Physicochemical parameters such as total ash, acid insoluble ash, alcohol soluble extractive, water soluble extractive, hexane soluble extractive values were assessed and safety evaluation studies such as microbial load, aflatoxin, heavy metal and pesticide residue analysis was carried out. The ethanolic extracts of leaf and seed are subjected to HPTLC and developed the fingerprint pattern.
\end{abstract}

\section{Introduction}

The plant Punica granatum L. belongs to family Punicaceae. A large deciduous shrub or a small tree, species is globally distributed in South Europe, Pakistan, India and West Asia. Within India, found as wild in the Western Himalayas between an altitude range of 900 to $2000 \mathrm{~m}$. Flowering occurs April to July, while fruiting period July to September, commonly known as pomegranate in English, Danima in Telugu, Suphala in Sanskrit, Anar in Unani, etc., and its seed as Anardana in Unani, etc. The plant crude materials study is an essential part in herbal drugs for the quality control. It basically deals with authentication, standardization and systematic study of plant-based raw drugs through morphological and physicochemical analysis. These studies ensure the reproducible quality of crude drugs and their safety and efficacy as herbal medicines (Sumitra, 2014). $P$. granatum has great nutritional values and numerous health benefits. The pomegranate is used in natural and holistic medicine to treat sore throats, coughs, urinary infections, skin disorders, arthritis intestinal parasites, dysentery and diarrhea (Al-Said et al., 2009). Clinical research studies suggest pomegranates when taken as a part of a healthy diet, might prevent heart diseases. Pomegranates have the potential to thin the blood, reduce blood pressure, reduce plaque in the arteries, increase blood flow to the heart and reduce bad cholesterol while increasing good cholesterol (Debjit et al., 2013).

Corresponding author: Dr. Mohammed Abdul Rasheed Naikodi Scientist, Drug Standardization Research Unit, National Research Institute of Unani Medicine for Skin Disorders, A.G. Colony Road, Erragadda, Hyderabad-500038, Telangana State, India

E-mail: rasheed.crium@gmail.com

Tel.: +91-9959840785

Copyright (c) 2021 Ukaaz Publications. All rights reserved.

Email: ukaaz@yahoo.com; Website: www.ukaazpublications.com
There are few reports available separately for the $P$. granatum fruit, leaves and seed (Amir et al., 2019; Pranay et al., 2019) where the adequate data for the standardization and proper evaluation was lacking. Further to mention that the work on leaf and seed has not been reported so far. So, our study will help researchers in their future studies. Therefore, we have made an attempt to study to generate scientifically evidence based data on the $P$. granatum leaf and seed through one of the most convenient and rapid analytical method having low cost to identify the samples.

Phytochemical constituents earlier reported to be present in leaf are rutin, luteolin, gallic acid, ellagic acid, punicalin, punicaligin (Amine et al., 2020). Anardana seed contains delphinidin-3glucoside, cyanidin-3-glucoside, pelargonidin-3,5-diglucoside, punicic acid, 4-methyl lauric acid, 1, 3- dimethyl stearic acid (Elfalleh et al., 2012). The green syntheses of silver nanoparticles from pomegranate are reported by few groups of researchers. The major plant parts are used as substrates for the synthesis of nanoparticles such as peel and seed juice. The study of silver nanoparticles in pomegranate are carried out by them (Nisha et al., 2015; Jobitha et al., 2013; Nisha et al., 2015a; Elia et al., 2014), whereas certain studies are reported with gold nanoparticles. Similar types of nanoparticles studies were carried and some are synthesized from various biological materials ranging from microorganisms (Krishna et al., 2013; Mahanty et al., 2013; Logeswari et al., 2013).

The present work aimed to study the leaf and seed of $P$. granatum for pharmacognostic parameters which provide a reliable basis, and also for the identification, standardization and quality control check of leaf and seed. Physicochemical studies, aflatoxins, heavy metals, pesticide residues, microbial load and high-performance thin layer chromatographic studies were carried out. 


\section{Material and Methods}

\subsection{Collection of plant material}

Punica granatum L. leaf and seed (Figure 1) were collected from the pharmacy and identified with the help of a Botanist, National Research Institute of Unani Medicine for Skin Disorders (NRIUMSD), Hyderabad. Leaf and seed thoroughly washed and cut in to pieces and further dried under shade at $28 \pm 2^{\circ} \mathrm{C}$ for about 15 days. The dried parts were stored in a closed container at room temperature.

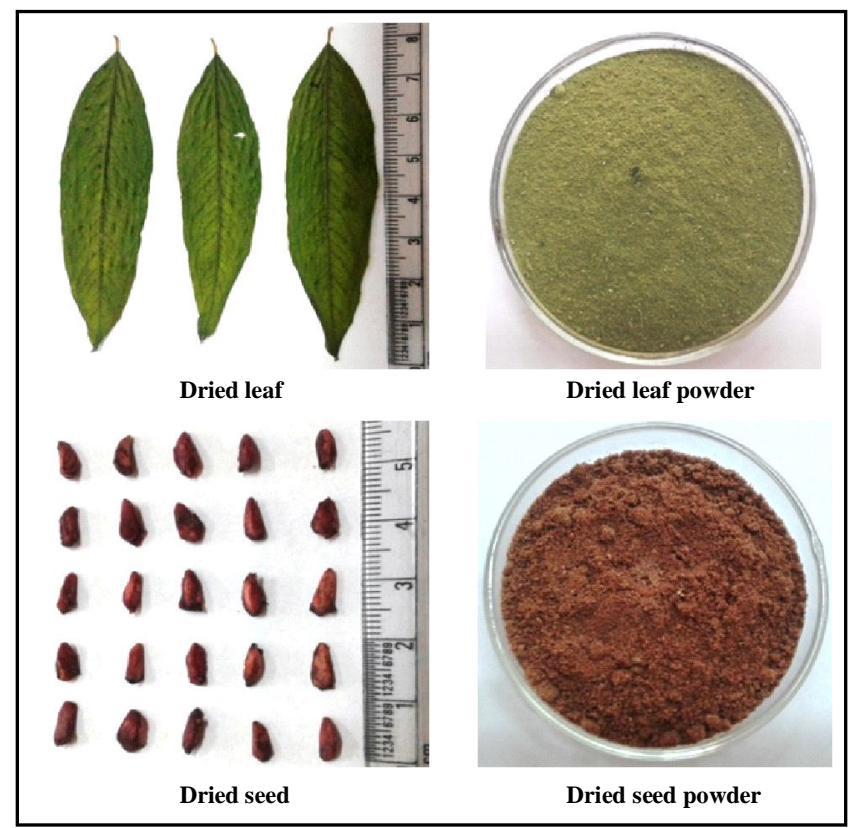

Figure 1: $P$. granatum dried leaf and seed along with powder form.

\subsection{Macroscopic features}

It involves the sensory characters of the samples like color, odour, taste, size and shape. Organoleptic characters are basically important in the preliminary examination of drugs (Kokate, 2003). The morphology of leaf and seed was studied and their corresponding characteristic were observed and recorded.

\subsection{Microscopic features}

Hand sections of leaf and seed of selected medicinal plant parts are taken and observed under digital microscope attached with computer system (Olympus Mic-D). The outer epidermal membranous layers (in fragments) were cleaned with chloral hydrate, mounted and then observed under microscope (Anonymous, 2007).

\subsection{Powder drug microscopy}

Powdered leaf and seed are evaluated for microscopic structures, each of them are separately stained with the respective reagents to determine characteristic features, viz., phloroglucinol $1 \%$ and conc. $\mathrm{HCl}$ (lignified structures), $\mathrm{H}_{2} \mathrm{SO}_{4}(350 \mathrm{~g} / \mathrm{l})$ (calcium oxalate crystals), iodine solution (starch granules), sudan red G (cuticular cell walls) and sudan red $\mathrm{G}$ in acetic acid and ethanol (essential oils, resins, fats and fatty oils) were used on bleached powders (WHO, 2011). All samples were observed under microscope.

\subsection{Physicochemical analysis}

Physicochemical parameters were studied as shown in Table 1 such as total ash, acid insoluble water and alcohol soluble extractive, and loss on drying at $105^{\circ} \mathrm{C}$. Physicochemical parameters were determined according to the methods described in The Unani Pharmacopoeia of India (Anonymous, 2009).

\subsection{Estimation of microbial load/heavy metals/aflatoxins/} pesticide residue

The microbial load, viz., total microbial plate count, total yeast and mould Salmonella spp., and Escherichia coli were estimated as per standard methods. The analysis of heavy metals like mercury, lead, cadmium and arsenic was carried out as per standard methods. Aflatoxins $B_{1}, B_{2}, G_{1}$ and $G_{2}$ were analyzed as per official analytical Methods of the American Spice Trade Association (WHO, 1998). The analysis of pesticide residues were carried out as per the method described in AOAC. Pesticide residues were analyzed by employing gas chromatography-mass spectrometry (GC-MS) (WHO, 1998; Anonymous, 1997; Anonymous, 2005).

\subsection{HPTLC fingerprint profile}

\subsubsection{Preparation of extracts}

Five grams of powdered leaf and seed each of $P$. granatum were extracted by reflux in soxhlet apparatus using ethanol as solvent separately. Later, the contents were removed and evaporate the solution to $20 \mathrm{ml}$. The solution thus obtained was used as sample for the HPTLC analysis.

\subsubsection{HPTLC method conditions}

HPTLC was performed on $10 \mathrm{~cm} \times 10 \mathrm{~cm}$ precoated aluminium thin layer chromatography (TLC) plates of Silica Gel $60 \mathrm{~F}_{254}$ (Merck). Sample extract of about $10 \mu \mathrm{l}$ were applied as $10 \mathrm{~mm}$ width bands using Automatic TLC applicator system of the DESAGA Sarstedt Gruppe (Germany). The ethanolic extract of Anar (leaf) applied in duplicates tracks 1 and 2 in TLC plate and ethanolic extract anardana (seed) applied in duplicates track 3 and 4 in TLC plate A. Linear ascending development with toluene: ethyl acetate: methanol (7:2:1 $v / v / v)$ as mobile phase was carried out in a twin trough glass chamber previously saturated with mobile phase vapour for $20 \mathrm{~min}$ at room temperature $\left(25 \pm 2^{\circ} \mathrm{C}\right)$. The development of solvent distance was $80 \mathrm{~mm}$. After development, plates were air-dried. After derivatization, TLC plate scanning was performed by densitometer of DESAGA SarstedtGruppe (Germany) at $580 \mathrm{~nm}$ wavelength and operated by Pro Quant 1.06 version software. The source of radiation was a deuterium lamp emitting a continuous UV spectrum in the range 190-400 $\mathrm{nm}$. The slit dimensions were $2 \mathrm{~mm} \times 4 \mathrm{~mm}$. After developing, the TLC plate was dried completely and detected by anisaldehyde sulphuric acid reagent on the plate heated at $120^{\circ} \mathrm{C}$ for $5 \mathrm{~min}$ and then observed in visible region and photographed as shown in Figure 6.

\section{Results}

The samples of anar (leaf) and anardana (seed) are subjected to pharmacognostic study including powder microscopy, physicochemical parameters such as total ash, acid insoluble ash, alcohol soluble extractive, water soluble extractive, hexane soluble extractive values and safety evaluation studies such as microbial load, aflatoxin, heavy metal and pesticide residue analysis, and ethanolic extracts of anar (leaf) and anardana (seed) are subjected to developed the HPTLC fingerprint pattern whose results are as given below. 


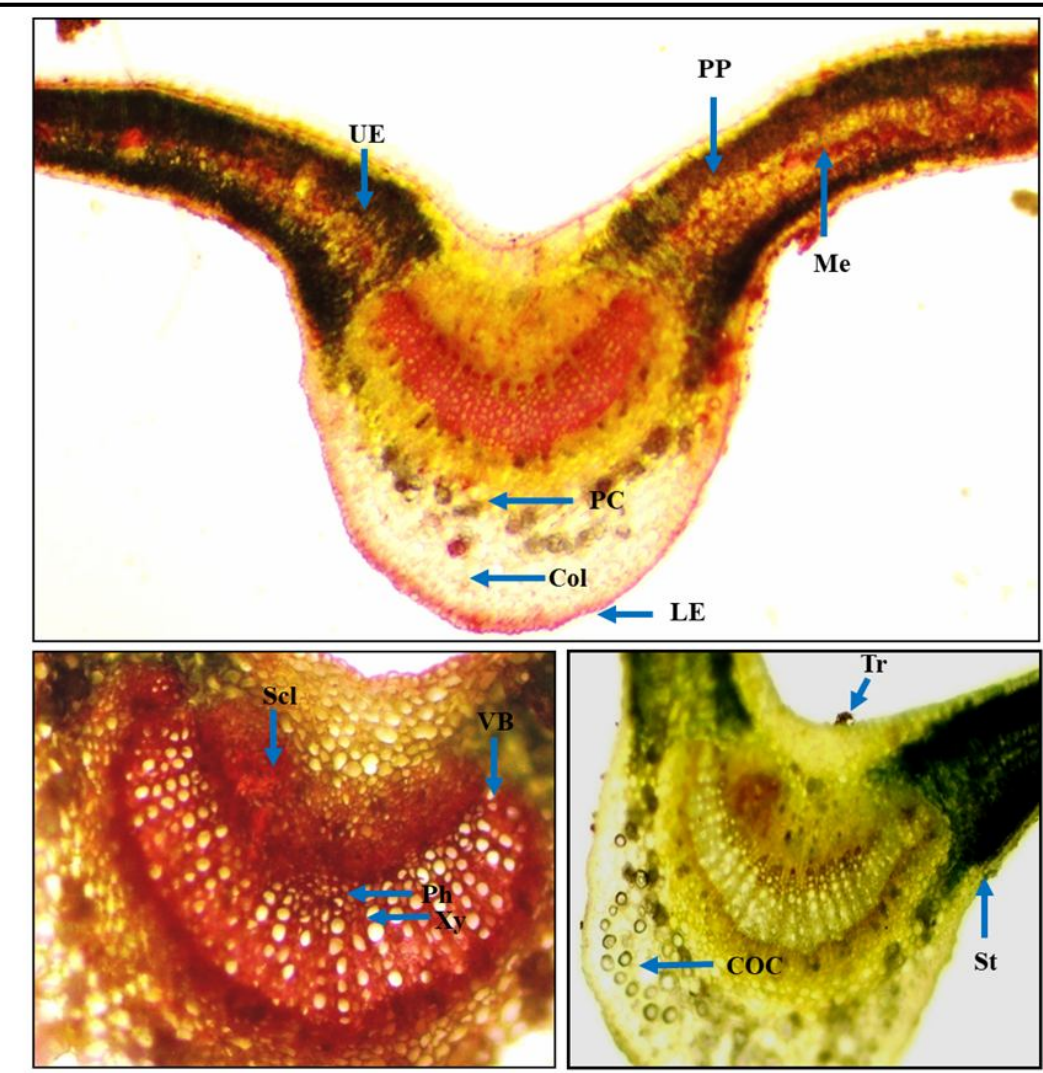

UE: Upper Epidermis; PP: PalisadeParenchyma; Me: Mesophyll cells; PC: Palisade cells;Col: Collenchyma; LE:Lower Epidermis; Scl: Sclerenchyma; VB: Vascular Bundle; Ph: Phloem; Xy: Xylem; COC: Calcium Oxalate Crystals; St: Stomata.

Figure 2: Microscopic study of anar leaf (P. granatum).

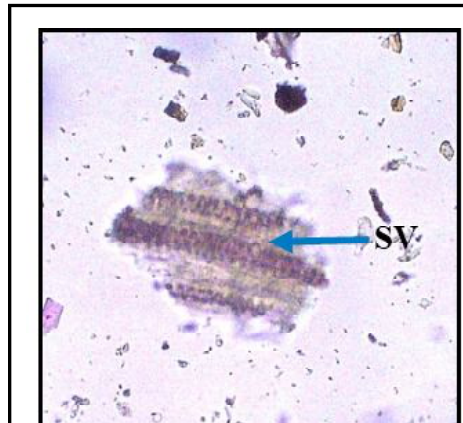

Spiral vessels

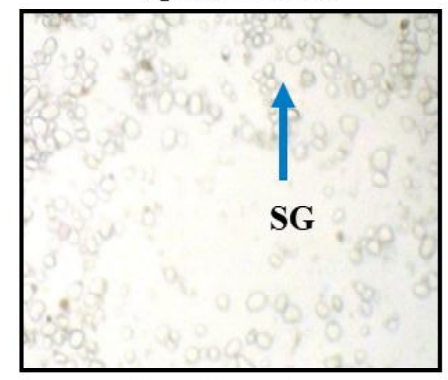

Starch grains

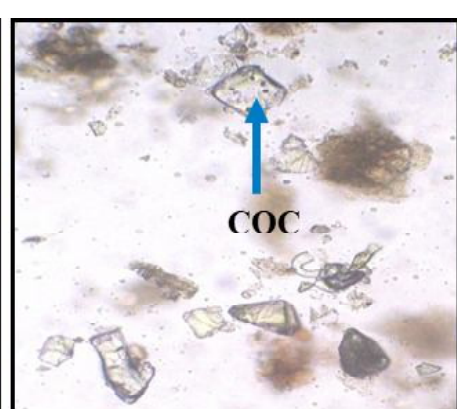

Calcium oxalate crystals

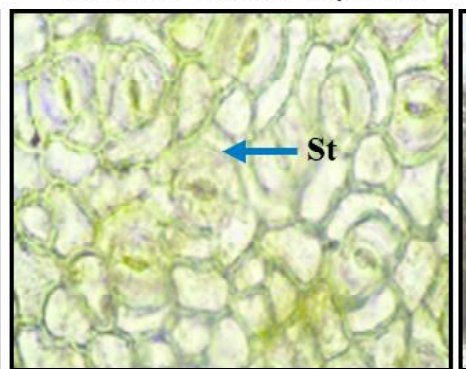

Stomata

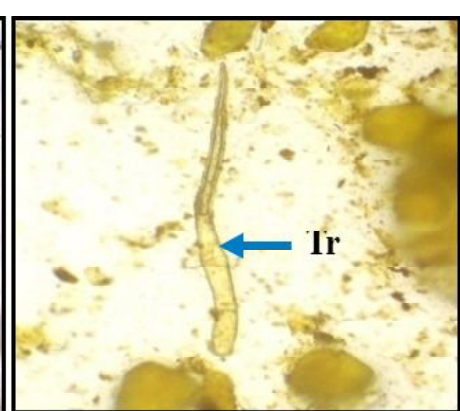

Trichomes

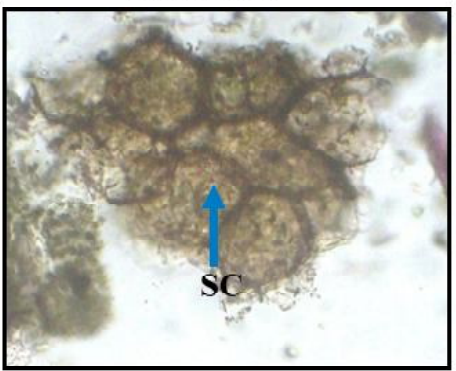

Sclerenchyma cells

Figure 3: Powder microscopy of anar leaf ( $P$. granatum). 

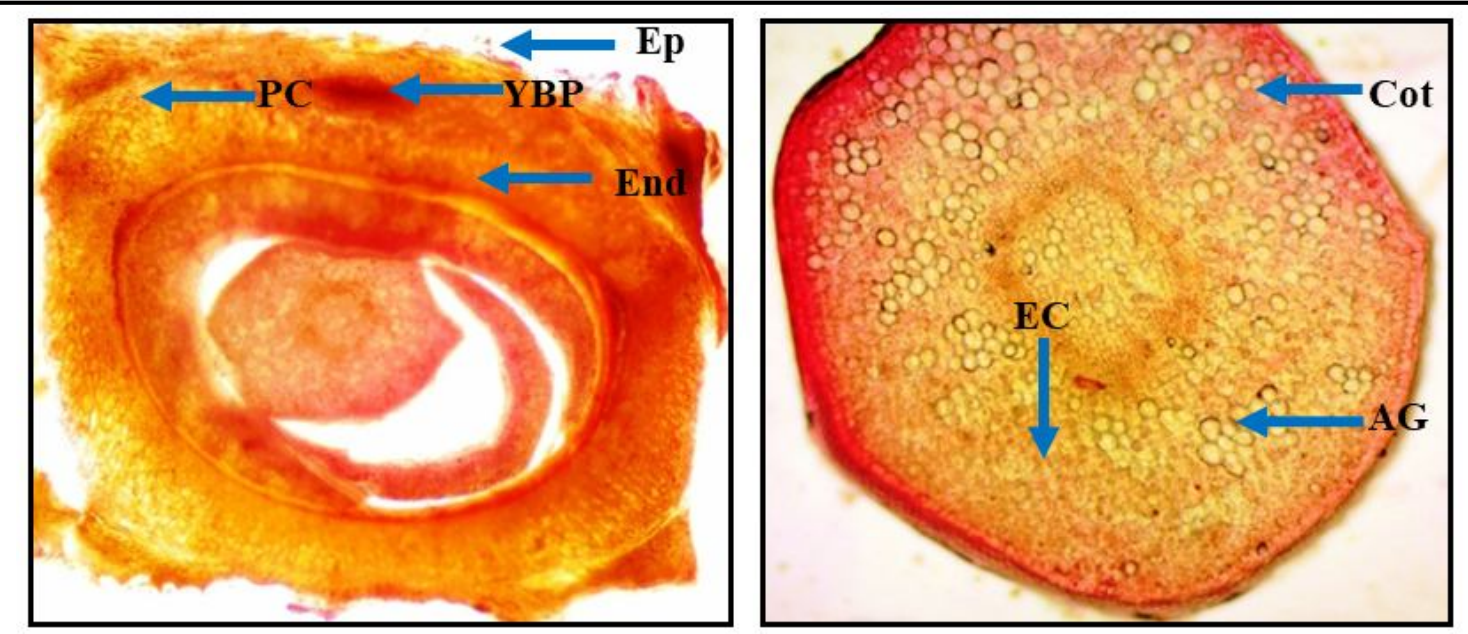

Ep: Epidermis; YBP: Yellowish brown pigment; PC: Parenchymatous cells; End: Endodermis; Cot: Cotyledons; EC: Endosperm cells; AG: Aleurone Grains.

Figure 4: Microscopic study of anardana seed (P. granatum).

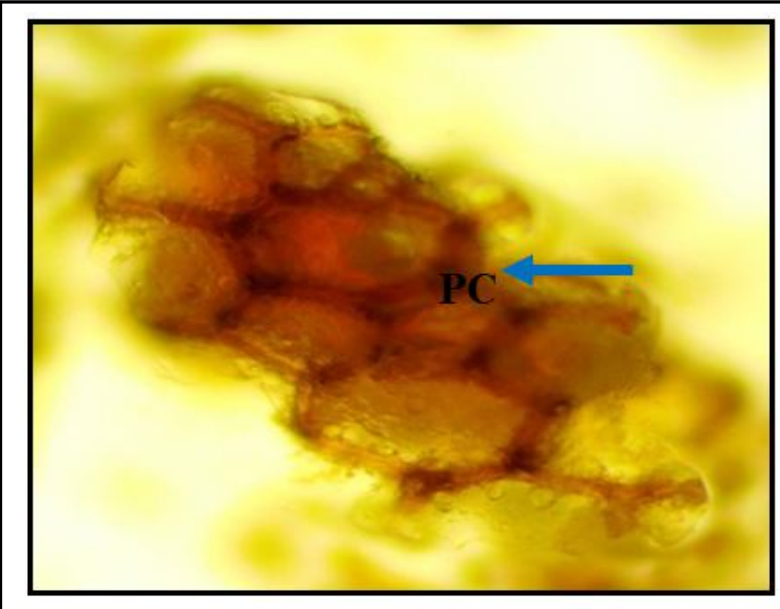

Parenchymatous cells

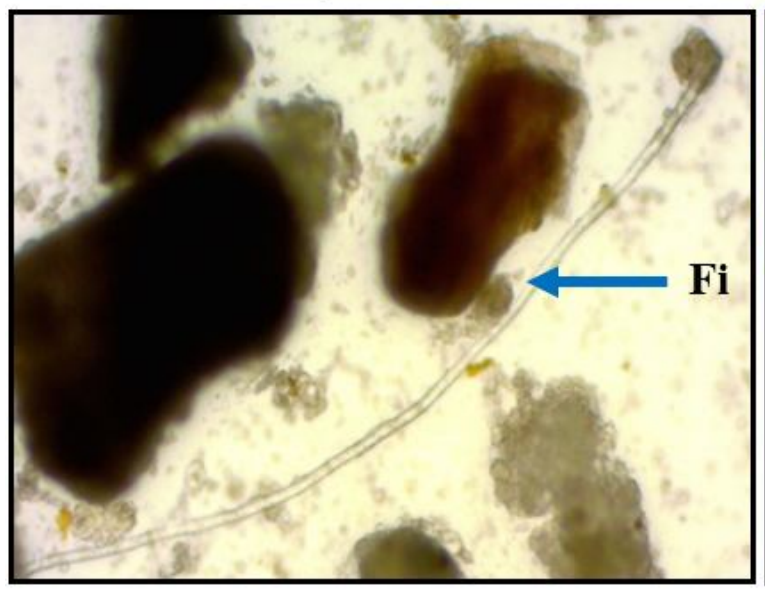

Fibres

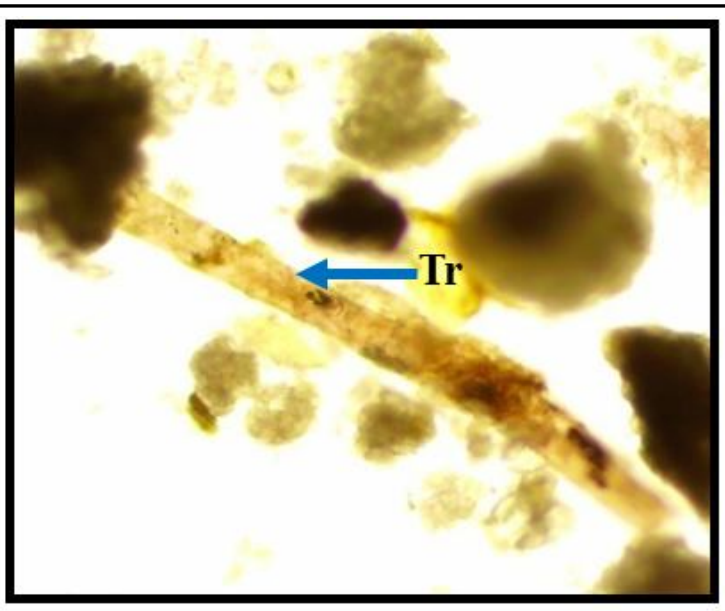

Tracheids

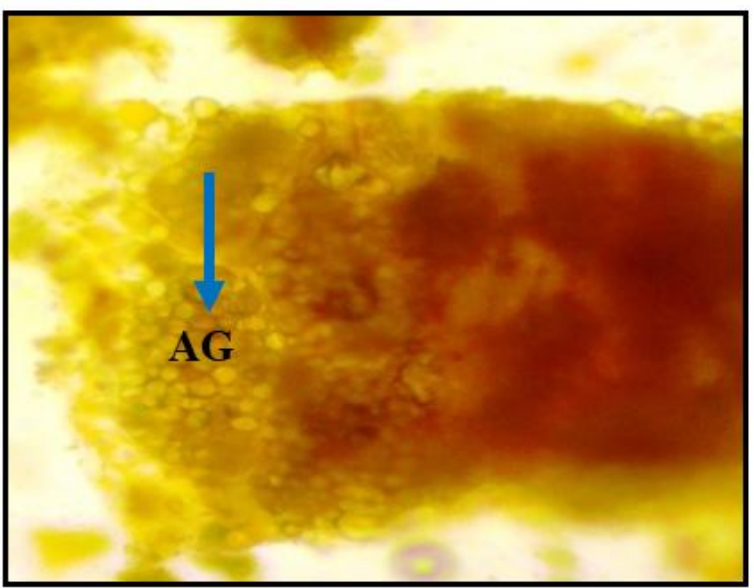

Aleurone grains

Figure 5: Powder microscopy of anardana seed (P. granatum). 


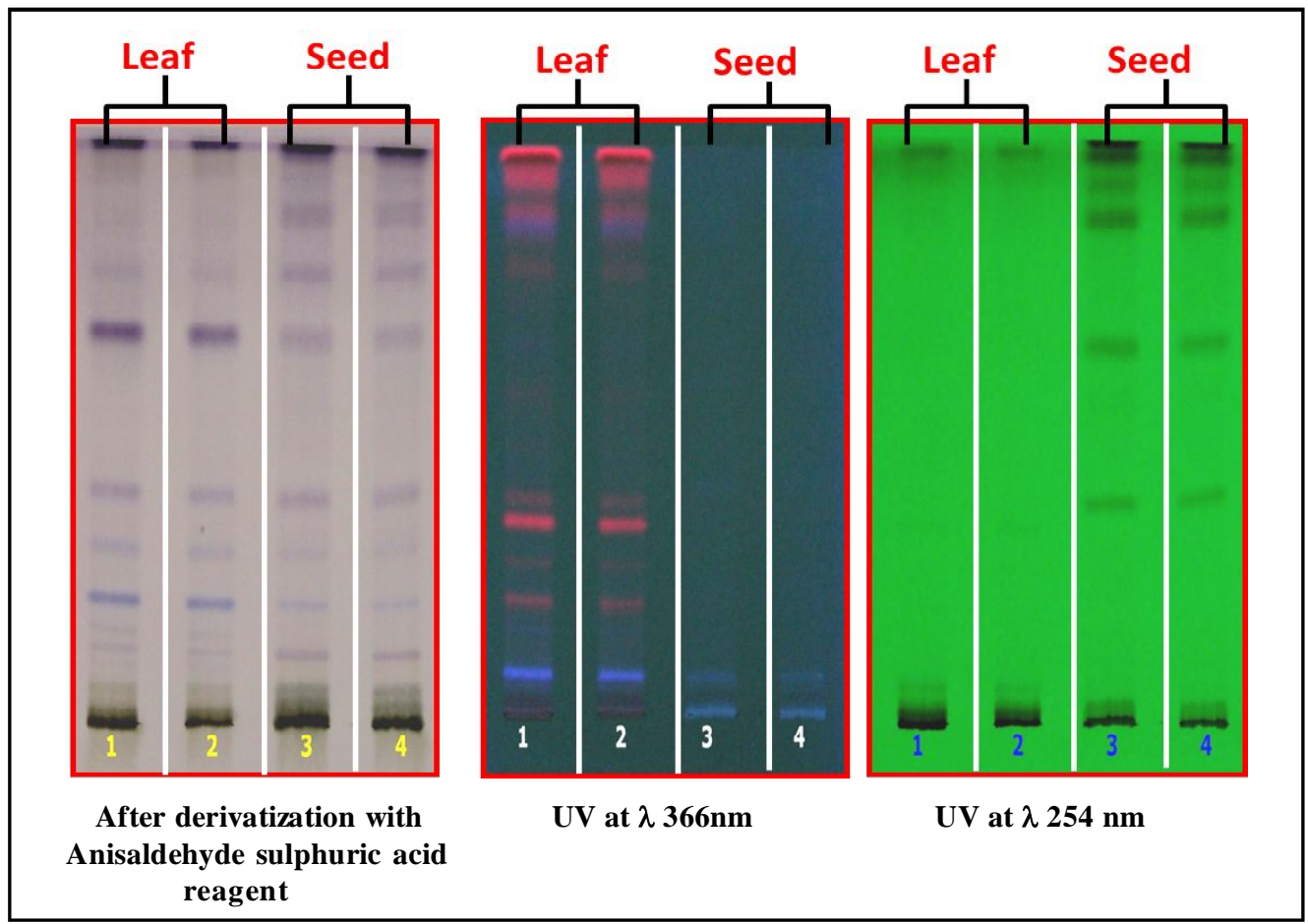

Figure 6: Thin layer chromatography plates of ethanolic extract of anar and anardana. Track 1, 2 = anar (leaf); Track 3, 4 = anardana (seed).

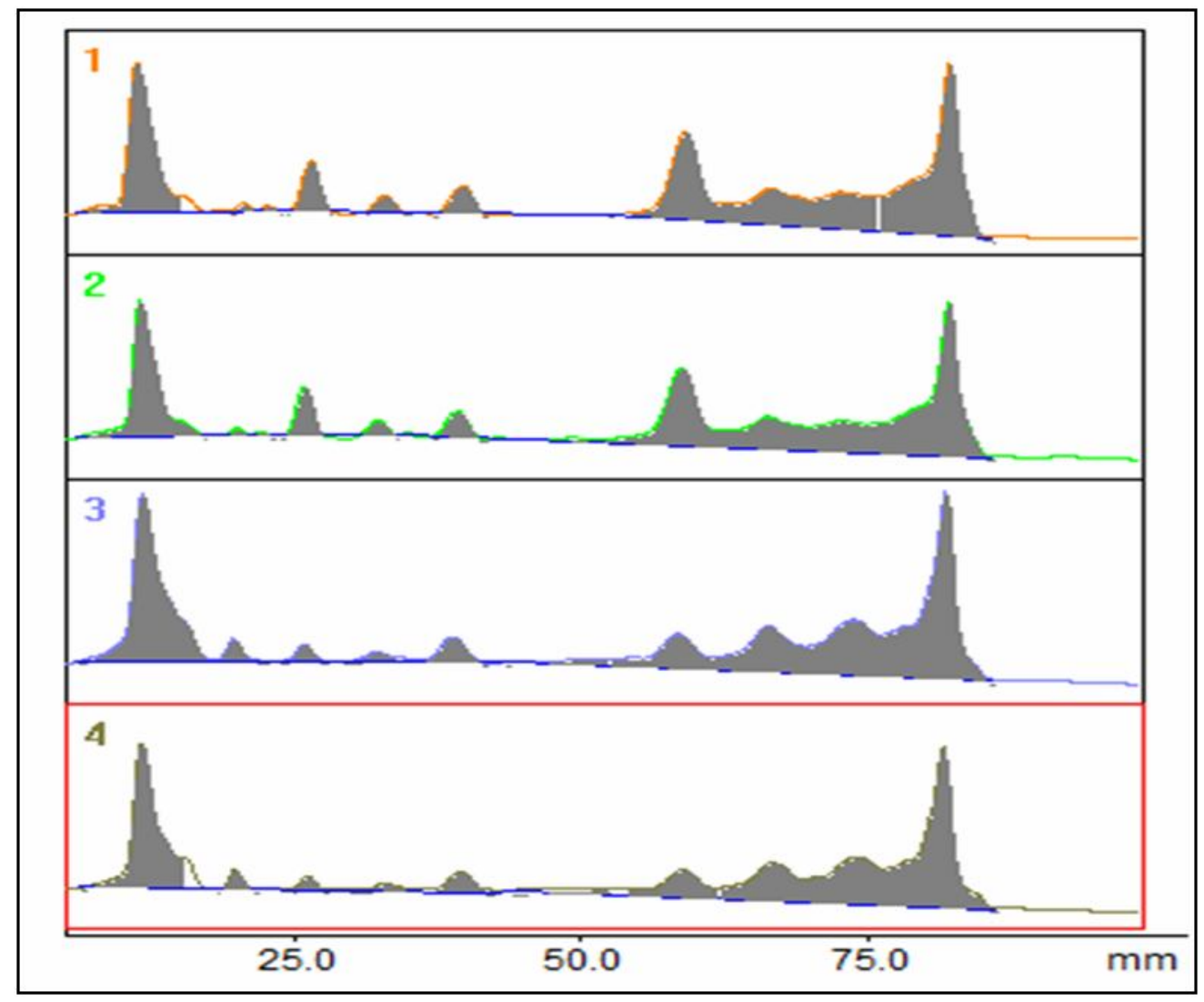




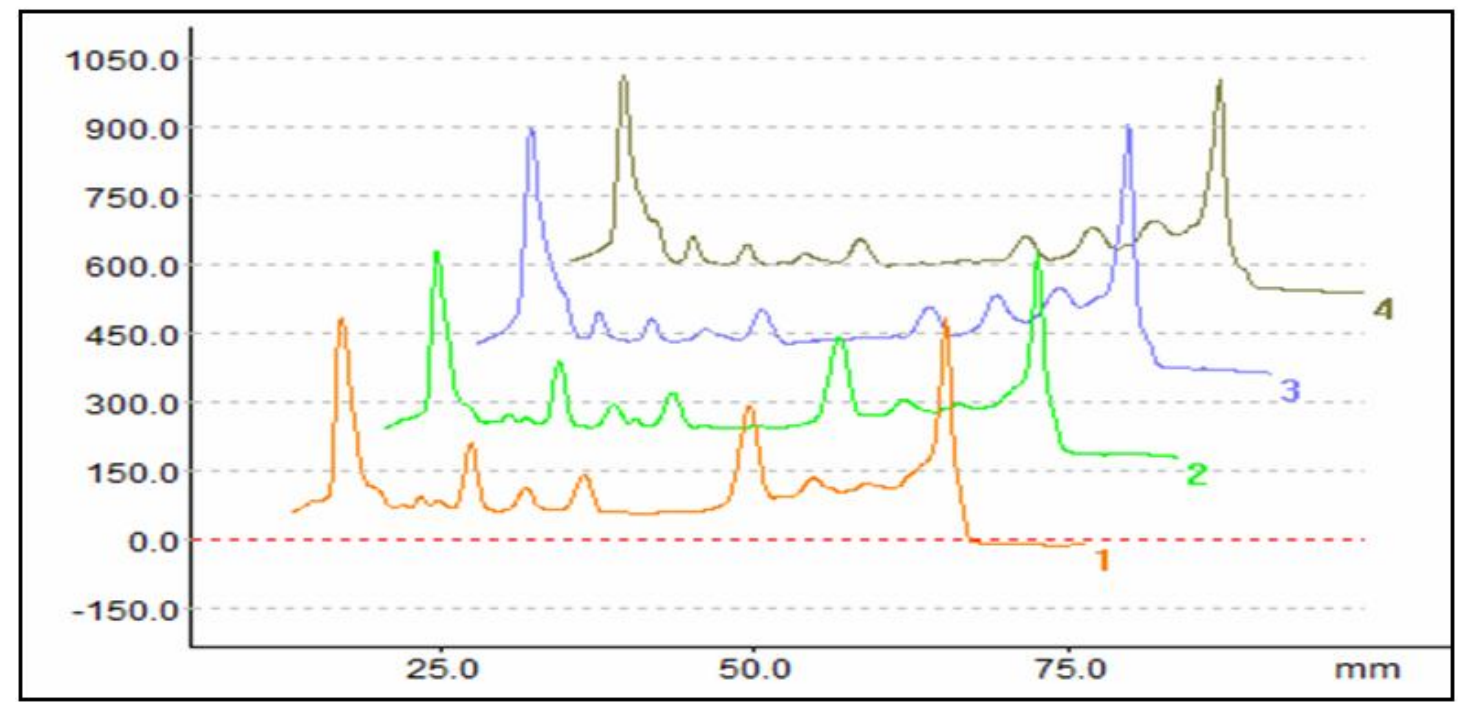

Figure 7: HPTLC densitograms of ethanolic extract of anar and anardana derivatized with anisaldehyde sulphuric acid reagent and scanned at $\lambda 580 \mathrm{~nm}$. (a) Vertical view, and (b) 3D view.

Table 1: Physicochemical parameters of P. granatum (leaf and seed)

\begin{tabular}{|c|l|c|c|}
\hline S. No. & Parameters analyzed & \multicolumn{2}{|c|}{ Results $(\% w / w)$} \\
\cline { 3 - 4 } & & Leaf & Seed \\
\hline 1. & Foreign matter & Nil & Nil \\
\hline 2. & Total ash & $08.52-09.02$ & $04.49-04.95$ \\
\hline 3. & Acid insoluble ash & $02.01-02.12$ & $00.69-00.75$ \\
\hline 4. & Alcohol soluble extractive & $24.42-25.04$ & $26.44-27.86$ \\
\hline 5. & Water soluble extractive & $34.06-35.16$ & $33.48-34.10$ \\
\hline 6. & Hexane soluble extractive & $03.29-03.45$ & $13.85-14.94$ \\
\hline 7. & Loss in wt. on drying at $105^{\circ} \mathrm{C}$ & $08.51-08.75$ & $11.69-12.45$ \\
\hline
\end{tabular}

Table 2: Peak list of ethanolic extract of anar and anardana after derivatized with anisaldehyde sulphuric acid reagent at $\lambda \mathbf{5 8 0} \mathrm{nm}$

\begin{tabular}{|c|c|c|c|c|c|c|}
\hline \multirow{2}{*}{$\begin{array}{c}\text { Sample } \\
\begin{array}{c}\text { Detection } \\
\text { system }\end{array}\end{array}$} & \multicolumn{3}{|c|}{ Anar (leaf) } & \multicolumn{3}{|c|}{ Anardana (seed) } \\
\hline & $\begin{array}{l}\text { Anisaldehyde } \\
\text { sulphuric } \\
\text { acid reagent }\end{array}$ & UV $366 \mathrm{~nm}$ & UV 254 nm & $\begin{array}{l}\text { Anisaldehyde } \\
\text { sulphuric } \\
\text { acid reagent }\end{array}$ & UV $366 \mathrm{~nm}$ & UV $254 \mathrm{~nm}$ \\
\hline Peak no & $\mathbf{R}_{f}$ value & $\mathbf{R}_{f}$ value & $\mathbf{R}_{f}$ value & $\mathbf{R}_{f}$ value & $\mathbf{R}_{f}$ value & $\mathbf{R}_{f}$ value \\
\hline 1 & 0.02 & 0.02 & 0.02 & 0.02 & 0.03 & 0.03 \\
\hline 2 & 0.14 & 0.08 & 0.08 & 0.13 & - & 0.41 \\
\hline 3 & 0.17 & 0.22 & 0.98 & 0.22 & - & 0.66 \\
\hline 4 & 0.23 & 0.35 & - & 0.31 & - & 0.88 \\
\hline 5 & 0.31 & 0.89 & - & 0.39 & - & 0.93 \\
\hline 6 & 0.41 & 0.99 & - & 0.56 & - & 0.98 \\
\hline 7 & 0.67 & - & - & 0.66 & - & 0.99 \\
\hline 8 & 0.78 & - & - & 0.77 & - & - \\
\hline 9 & 0.86 & - & - & 0.87 & - & - \\
\hline 10 & 0.99 & - & - & 0.98 & - & - \\
\hline
\end{tabular}




\section{Discussion}

\subsection{Macroscopic features of anar leaf}

Leaves are green, opposite or sub opposite, petiolate, ovate, glossy, narrow oblong, subsessile and exstipulate, 3 to $8 \mathrm{~cm}$ long and 0.5 to $2.5 \mathrm{~cm}$ broad, narrow at both the ends, especially at the base. Leaf is a characteristic odour and astringent taste.

\subsection{Microscopic features of anar leaf}

Transverse section of leaf lamina shows upper and lower epidermis. The lamina is rectangular and tangentially elongated in shape. The anomocytic and anisocytic stomata were present in epidermis whereas, unicellular trichomes were present in lamina but less in number. Outer walls of lower and upper epidermal cells have thin layer of cuticle. Mesophyll consists of single layer of palisade cells and 3 to 6 layers of spongy parenchyma as shown in Figure 2. Midrib shows lower and upper epidermis, there is a layer of collenchyma cells. Between the collenchyma and vascular arc lies the cortex consisting of 5 to 8 layers of thin walled parenchymatous cells. Vascular bundles were arc shaped, prismatic and cluster types of crystals of calcium oxalate are found. Spiral and annular types of xylem vessels are observed. Stomatal index 22.5 to 24.8 , palisade ratio 6.8 to 10.5 , vein islet number 29.5 to 34.0 per sq. $\mathrm{mm}$ as shown in Figure 2.

\subsection{Powder features of anar leaf}

Powder light brown in colour having characteristic odour and astringent taste. Calcium oxalate crystals present on surface of epithelial cells. Simple and compound starch grains are present. Fragments of epidermis were embedded with stomata. Xylem vessels with spiral and reticulated annular thickenings. Parenchyma and sclerenchyma cells were observed and are as shown in Figure 3.

\subsection{Macroscopic features of anardana seed}

Seeds are irregularly ovoid, flattened and angular about $0.5 \mathrm{~cm}$ long. Seed is anatropous, non-endospermic and exarillate and developed from a bitegmic. Testa is coriaceous, composed of fleshy edible sarcotesta and thick walled hard sclerotic mesotesta. Outer coat which is red in color, sweet taste and agreeable sweet odour.

\subsection{Microscopic features of anardana seed}

Transverse section of seed consists of outer and inner epidermis. Outer epidermis is 4 to 5 cell walled thick membranous structure. Single layer epidermis is thick walled membranous structure. Single layer epidermis is thick walled longitudinal and elongated cells forming chain like structure surrounding the cotyledons. Testa which is consisting of large multilayered thin walled parenchymatous cells. It shows longitudinal tracheids with spiral and annular thickenings. Testa is followed by a single layer of thick walled cells containing yellowish brown content. Endosperm cells develop in the centre and merge with the embryo. Cotyledons are two in number made up of single layer, thin walled parenchymatous cells containing abundant aleurone grains as shown in Figure 4.

\subsection{Powder features of anardana seed}

Powder shows light red in color, sweet taste and agreeable sweet odour. Presence of fragments of xylem fibres, thin walled parenchymatous cells containing aleurone grains. It showed tracheids with spiral and annular thickenings as shown in Figure 5.

\subsection{Physicochemical parameters}

The physicochemical parameters are expressed as in range for leaf and seeds as depicted in Table 1 . In leaf, the total ash and acid insoluble ash was found in the range of 8.52-9.02 and 2.01-2.12\% $/$ $w$, respectively; whereas alcohol, water and hexane soluble extractivein terms of $\% w / w$ was found in the range of 24.42-25.04, 34.06-35.16 and 3.29-3.45\% $\mathrm{w} / \mathrm{w}$, respectively and loss of weight on drying at $105^{\circ} \mathrm{C}$ found in the range of $8.51-8.75 \% w / w$. Similarly, in the case of seed, the total ash and acid insoluble ash was found in the range of 4.49-4.95 and 0.69-0.75\% \% $/ w$, respectively; whereas alcohol, water and hexane soluble extractive in terms of $\% \mathrm{w} / \mathrm{w}$ was found in the range of 26.44-27.86, 33.48-34.10 and 13.85-14.94 $\% w / w$, respectively and loss of weight on drying at $105^{\circ} \mathrm{C}$ found in the range of $11.69-12.45 \% w / w$ as tabulated in Table 1.

\subsection{HPTLC analysis}

The ethanolic extract of anar (leaf) track 1 and 2 in thin layer chromatograhphy (TLC) plate: the TLC plate after derivatizing with anisaldehyde sulphuric acid reagent and heating at $120^{\circ} \mathrm{C}$ shows eight spots at $\mathrm{R}_{f}$ values $0.14,0.17,0.22,0.31,0.41,0.68,0.78,0.88$ (all purple); whereas under UV $\lambda 366 \mathrm{~nm}$, the TLC plate shows ten major spots at $\mathrm{R}_{f}$ values 0.07 (blue), 0.21 (red), 0.25 (red), 0.32 (red), 0.37 (red), 0.78 (red), 0.88 (red), 0.92 (red), 0.95 (red), 0.98 (red); and under UV $\lambda 254 \mathrm{~nm}$ no spots are observed. On the other hand, the ethanolic extract of anardana (seed) track 3 and 4 in TLC plate after derivatizing with anisaldehyde sulphuric acid reagent and heating at $120^{\circ} \mathrm{C}$ shows nine spots at $\mathrm{R}_{f}$ values $0.07,0.14$, $0.21,0.31,0.41,0.68,0.80,0.90,0.97$ (all purple); and under UV $\lambda$ $366 \mathrm{~nm}$ the TLC plate show two major spots at $\mathrm{R}_{f}$ values 0.07 (blue), 0.40 (blue).; and under UV $\lambda 254 \mathrm{~nm}$ the TLC plate shows five major spots at $\mathrm{R}_{f}$ values $0.40,0.67,0.88,0.94,0.97$ (all black) as shown in Figure 6. The densitograms of ethanolic extract of anar and anardana after derivatized with anisaldehyde sulphuric acid reagent and scanned at wave length with HPTLC densitometer at $\lambda$ $580 \mathrm{~nm}$ and the obtained densitogram was shown in Figure 7. The peak list, peak areas in densitogram at $\lambda 580 \mathrm{~nm}$ of ethanolic extract of anar and anardana after derivatizing with anisaldehyde sulphuric acid reagent are shown in Table 2.

\subsection{Evaluation of drug quality parameters}

The quality of drug samples, the microbial loads such as total microbial plate count, total yeast and mould count, Escherichia coli, Salmonella spp., were analyzed and found within the permissible limit. The heavy metals lead, cadmium, mercury and arsenic were found to be below detection limit in the drug samples. Moreover, aflatoxins $B_{1}, B_{2}, G_{1}$ and $G_{2}$ are found below the limit of quantification. Pesticide residue analysis such as alachlor, aldrin and dieldrin, azinphosmethyl, bromopropylate, chlordane, chlorfenvinphos, chlorpyrifos, chlorpyrifosmethyl, cypermethrin, DDT, deltamethrin, diazinon, dichlorvos, dithiocarbamates, endosulfan, endrin, ethion, fenitrothion, fenvalerate, fonofos, heptachlor, hexachlorobenzene, hexachlorocyclohexane isomers, lindane, malathion, methidathion, parathion, parathion-methyl, permethrin, phosalone, piperonyl butoxide, pirimiphos-methyl, pyrethrins, quintozene were also found below the limit of quantification as per WHO (1998). The study indicates that the drug samples are free from contaminations such as microbial, heavy metals, aflatoxin and pesticide residue. 


\section{Conclusion}

Standardization of plant drugs is very much crucial since they are produced from heterogeneous sources which could result in variations. Qualitative and quantitative microscopic features would serve for lay down pharmacopoeial standards. Pharmacognostic studies on the whole provide useful data for identifying and authenticating crude drugs. In our study, detailed description of the pharmacognostic features of the leaf and seed of $P$. granatum has been thoroughly studied. In the present study, standardization of anar leaf and anardana seed has been successfully done and the HTPLC fingerprint will serve to identify and authenticate the samples of quality control check in as a reference standard and using the developed novel HPTLC method, one can easily identify and confirm at once the samples of leaf and seed of P. granatum.

\section{Acknowledgments}

The authors are thankful to the Director General, CCRUM, New Delhi, and also Director, NRIUMSD, Hyderabad for providing the necessary facilities.

\section{Conflict of interest}

The authors declare no conflict of interest related to this article.

\section{References}

Al Said, F.; Opara, L. and Al Yahyai, R.A. (2009). Physical, chemical and textura quality attributes of pomegranate cultivars (Punica granatum L.) grown in the Sultanate of Oman. Journal of Food Engineering, 90(1): 129-134.

Amine, T.; Mohamed, A.; Aimen, A.; Amira, H.; Leila, C.G. and Kamel, G. (2020). Phytochemical study and antibacterial and antibiotic modulation activity of Punica granatum (Pomegranate) leaves. Hindawi Scientifica, Vol. 2020, article ID 8271203, 1-7. https://doi.org/ $10.1155 / 2020 / 8271203$.

Amir, M.; Ahmad, N.; Sarfaroz, M.; Ahmad, W.; Ahmad, S. and Mujeeb. M. (2019). Pharmacognostical, physicochemical standardization and in vitro antioxidant activity of Punica granatum Linn fruit. Pharmacognosy Journal, 11(2):272-277. DOI:10.5530/pj.2019.11.42

Anonymous, (1997). Official analytical methods of the American Spice Trade Association (ASTA). Inc. $4^{\text {th }}$, New Jersey, USA.

Anonymous, (2005). Official methods of analysis. In: Horwitz W, Latimer G.W (eds.). AOAC International; Maryland, Chapter 3, pp:10-11.

Anonymous, (2007). The Unani Pharmacopoeia of India, Part-I, Vol. 2. Department of AYUSH, Ministry of Health and Family Welfare, Government of India.

Anonymous, (2009). The Unani Pharmacopoeia of India, Part-I, Vol. 6. Department of AYUSH, Ministry of Health and Family Welfare, Government of India, pp:3.
Debjit, B.; Harish, G; Kumar, B.P.; Duraive, S.; Aravind, G. and Kumar, K.P.S. (2013). Medicinal uses of Punica granatum and its health benefits. Journal of Pharmacognosy and Phytochemistry, 1(5):28-35.

Elfalleh, W.; Hannachi, H.; Tlili, N.; Yahia, Y.; Nasri, N. and Ferchichi, A. (2012). Total phenolic contents and antioxidant activities of pomegranate peel, seed, leaf and flower. Journal of Medicinal Plants Research, 6(32):4724-4730.

Elia, P.; Zach, R.; Hazan, S.; Kolusheva, S.; Porat, Z. and Zeiri, Y. (2014). Green synthesis of gold nanoparticles using plant extracts as reducing agents. International Journal of Nanomedicine, 9(1):4007-4021.

Jobitha, G.G.; Shanmugam, R.K.; Gurusamy, A. and Kannan, C. (2013). Preparation and characterization of fruit-mediated silver nanoparticles using pomegranate extract and assessment of its antimicrobial activities. Journal of Environmental Nanotechnology, 2(1):4-10.

Kokate, C.K.; Purohit, A.P. and Gokhale, S.B. (2003). Pharmacognosy-Nirali Prakashan, Pune, India, pp:1-624.

Krishna, P.S.; Prasad, M.R.; Krishna, G. and Singaracharya, M.A. (2013). Synthesis of silver nanoparticles from marine bacteria Pseudomonas aeruginosa. Octa Journal of Bio. Sciences, 1(2):108-114.

Logeswari, P.; Silambarasan, S. and Abraham, J. (2013). Ecofriendly synthesis of silver nanoparticles from commercially available plant powders and their antibacterial properties. Scientia Iranica, 20(3):10491054 .

Mahanty, A.; Bosu, R.; Panda, P.; Netam, S.P. and Sarkar, B. (2013). Microwave assisted rapid combinatorial synthesis of silver nanoparticles using E. coli culture supernatant. International Journal of Pharma. and Biosciences, 4(2):1030-1035.

Nisha, M.H.; Tamileaswari, R. and Jesurani, S. (2015). Analysis of antibacterial activity of silver nanoparticles from pomegranate (Punica granatum) seed and peel extracts. International Journal of Engineering Research and Technology, 4(4):1044-1048.

Nisha, M.H.; Tamileswari, R.; Jesurani, S.; Kanagesan, S.; Hashim, M.; Catherine, S. and Alexander, P. (2015a). Green synthesis of silver nanoparticles from pomegranate (Punica granatum) leaves and analysis of antibacterial activity. International Journal of Advanced in Engineering and Science, 3(6):1-8.

Pranay, W.; Saxena P.R.; Saraswat, N. and Yadav, R. (2019).Pharmacognostic evaluation and standardization of the leaves of Punica granatum. Research Journal of Pharmacy and Technology, 12(7):3255-3260. doi: 10.5958/0974-360X.2019.00549.3

Sumitra, C. (2014). Importance of pharmacognostic study of medicinal plants: An overview. Journal of Pharmacognosy and Phytochemistry, 2(5):69-73.

WHO. (1998). Quality control methods for medicinal plant materials, WHO, Geneva.

WHO. (2011). Quality control methods for medicinal plant materials. A.I.T.B.S. Publishers and Distributors. Delhi. 